\title{
STRATEGI PENGEMBANGAN BISNIS SAPI PEDAGING KELOMPOK TERNAK BERKAH USAHA DI BLORA
}

\author{
Ilham Dzikri Fajrianto'), dan Suprehatin2) \\ 1)Program Sarjana Agribisnis, Fakultas Ekonomi dan Manajemen, Institut Pertanian Bogor \\ 2)Departemen Agribisnis, Fakultas Ekonomi dan Manajemen, Institut Pertanian Bogor \\ Jl. Kamper Wing 4 Level 5 Kampus IPB Dramaga, Indonesia \\ 1)e-mail: kangdzikri97@gmail.com
}

(Diterima 4 Februari 2020 / Disetujui 17 Februari 2020)

\begin{abstract}
Farmer's group Berkah usaha at the beginning originally had two types of livestock businesses which are cattle and sheep. However, Berkah Usaha is focusing on cattle only. The development of the cattle business in this group is important to fulfil the increasing national demand for beef each year. This development of cattle business is also in line with the program of the local government of Blora which is making this district as a centre of cattle farm production. This study aims to formulate the cattle business development strategy for Berkah Usaha group by identifying the main internal and external factors. The study used four key informants as a respondent to identify the group's business environment and formulate business strategies. The analytical method used are IFE, EFE, IE, and SWOT matrix. The results showed that the Berkah Usaha's main internal key factors are cattle feed business and qualified cattle breeds while the main external key factors are government policies and climate variability. The results of this study also showed that there are six alternative business development strategies such as collaboration to develop regional livestock cluster and procurement of good cattle breeds.
\end{abstract}

Keywords: business strategy formulation, cattle beef, farmer group, regional livestock cluster

\begin{abstract}
ABSTRAK
Kelompok ternak Berkah Usaha pada awal berdirinya memiliki dua jenis usaha ternak yaitu sapi dan domba. Namun saat ini kelompok Berkah Usaha hanya fokus pada penggemukan sapi. Seiring dengan permintaan daging sapi yang terus meningkat, pengembangan usaha ternak sapi di kelompok ini sangat penting dilakukan. Hal ini juga sejalan dengan program pemerintah Kabupaten Blora yaitu menjadikan daerah ini sebagai sentra peternakan sapi. Penelitian ini bertujuan memformulasikan strategi pengembangan usaha ternak sapi pada kelompok Berkah Usaha dengan mengidentifikasi faktor kunci utama eksternal dan internal. Penelitian ini menggunakan empat narasumber kunci sebagai responden untuk mengidentifikasi lingkungan usaha kelompok dan merumuskan strategi. Metode analisis yang digunakan yaitu matriks IFE, EFE, IE, dan SWOT. Hasil penelitian menunjukkan bahwa faktor kunci utama internal pengembangan usaha ini yaitu usaha pakan ternak dan bakalan sapi yang berkualitas sedangkan faktor kunci utama eksternal yaitu kebijakan pemerintah dan variabilitas iklim. Hasil penelitian juga menunjukkan ada enam rumusan alternatif strategi pengembangan usaha pada kelompok ternak Berkah Usaha diantaranya kerjasama membangun kawasan peternakan sapi pedaging dan pengadaan bakalan sapi berkualitas.
\end{abstract}

Kata kunci: formulasi strategi bisnis, kawasan peternakan, kelompok ternak, sapi pedaging

\section{PENDAHULUAN}

\section{LATAR BELAKANG}

Seiring dengan transformasi pasar pangan dan pertanian (agri-food market transformation) yang terjadi di Indonesia, diantaranya disebabkan oleh faktor pertumbuhan ekonomi, urbanisasi, perubahan demografi, kebutuhan produk pertanian bernilai tinggi (high value agricultural products) masyarakat Indonesia terus meningkat (Reardon et al., 2015). Peningkatan kebutuhan pertanian bernilai tinggi tersebut diantaranya adalah produk-produk hasil ternak seperti telur, susu dan daging.

Bagi masyarakat Indonesia, daging menjadi salah satu asupan gizi yang penting karena 
diperlukan sebagai sumber protein hewani. Berbagai macam jenis daging yang umum dikonsumsi oleh sebagian besar masyarakat Indonesia yaitu daging sapi, kambing, domba, kerbau, ayam, dan bebek. Pada tahun 2016 tingkat konsumsi daging per kapita di Indonesia sebesar 6,78 kilogram, atau sekitar 5,69 persen lebih tinggi dari tingkat konsumsi pada tahun 2015 yang mencapai 6,41 kilogram (Ditjen PKH 2017).

Di sisi lain, produksi masing-masing daging ternak di Indonesia sangat beragam dengan produksi daging utama yaitu daging dari ayam ras pedaging dan sapi. Meskipun demikian, tren produksi kedua daging ternak tersebut berbeda pada tahun 2014-2017 dimana tren produksi daging sapi cenderung meningkat sebesar 11,3 ton per tahun sedangkan tren produksi daging ayam berfluktuasi (Ditjen PKH 2017).

Meskipun produksi daging sapi yang meningkat dan mengalami tren yang positif, namun produksi dalam negeri belum mampu memenuhi kebutuhan daging sapi dalam negeri dan target swasembada daging sapi yang dicanangkan pemerintah. Akibatnya impor daging di Indonesia tetap diperlukan untuk memenuhi keutuhan daging sapi dalam negeri (Gambar 1).

\section{(ribu ton)}

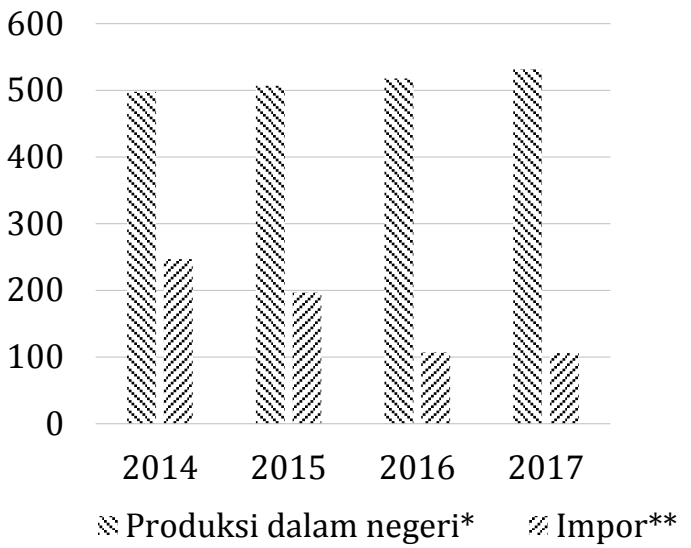

Gambar 1. Perbandingan Impor dan Produksi Daging Sapi di Indonesia Tahun 2014-2017 Sumber: *BPS (2018a), **Kementan (2017)

Gambar 1 menunjukkan bahwa produksi daging sapi dalam negeri terus meningkat, sedangkan tren impor mengalami penurunan. Meskipun demikian, untuk mencapai target swasembada daging sapi masih banyak yang harus diperbaiki dalam peningkatan produksi daging sapi dalam negeri termasuk pengembangan sentra peternakan berbasis peternakan sapi rakyat.

Secara umum, beragam progam sudah dilakukan oleh pemerintah diantaranya program Upsus Siwab (Upaya Khusus Sapi Indukan Wajib Bunting), bantuan modal untuk pembelian bakalan sapi unggul dan penguatan kelembagaan peternak melalui kelompok tani atau sekolah peternakan rakyat. Program-program tersebut dilakukan terutama di daerah sentra produksi sapi pedaging di Indonesia yaitu Jawa Timur, Jawa Tengah, Sulawesi Selatan, Nusa Tenggara Barat, dan Nusa Tenggara Timur. Populasi sapi pedaging di kelima provinsi sentra produksi tersebut mencapai 9.8 juta ekor sapi $(59,23$ persen) dari total populasi sapi pedaging di Indonesia tahun 2017 (BPS 2018).

Meskipun demikian, permasalahan yang dialami oleh sebagian besar daerah sentra peternakan sapi pedaging di Indonesia adalah skala usaha yang kecil. Pada tahun 2013 sebanyak 12,3 juta ekor (97,8 persen) ternak sapi berada di 5,1 juta rumah tangga usaha peternakan (ruta) (Ismono et al., 2015). Sisanya sekitar 2,2 persen berada di perusahaan berbadan hukum, pedagang, kelompok, dan lainnya. Dengan demikian, skala sapi pedaging di tingkat rumah tangga hanya berkisar rata-rata 2-3 ekor per ruta. Hal ini diduga menjadi salah satu faktor penyebab pertumbuhan populasi sapi pedaging nasional cenderung lambat, yaitu hanya sekitar 5,33 persen per tahun. Dengan ukuran populasi yang kecil dan skala usaha sebagian besar juga kecil, harapan untuk mencapai target swasembada daging sapi skala nasional memerlukan upaya strategi pengembangan dan perencanaan yang lebih baik, dari tingkat makro (nasional) sampai mikro (kelompok ternak/peternak).

\section{PERUMUSAN MASALAH}

Salah satu daerah sentra populasi sapi pedaging yang terus berkembang adalah Kabupaten Blora. Seperti halnya di daerah sentra produksi sapi pada umumnya, produksi sapi pedaging di Kabupaten Blora masih didominasi peternakan rakyat. Selain itu, sebagian besar peternakan di Kabupaten Blora pengelolaannya masih meng- 
gunakan sistem rumah tangga (ruta). Hal ini diduga menjadi salah satu hambatan dalam meningkatkan produksi daging sapi, karena apabila pengelolaan sistem yang diterapkan masih skala rumah tangga dan mengandalkan sistem budidaya secara tradisional maka dapat diprediksi bahwa pertumbuhan produksi daging sapi cenderung lambat.

Beragam upaya sudah dilakukan oleh pemerintah Blora untuk meningkatkan produktivitas para peternak diantaranya dengan mendorong mereka untuk bergabung dalam kelompok ternak dalam pengelolaan usaha ternak mereka. Salah satu kelompok yang bergerak pada penggemukan sapi pedaging adalah kelompok ternak Berkah Usaha. Kelompok ternak ini berdiri tahun 2016 yang pada awalnya memiliki dua jenis usaha ternak yaitu sapi dan domba. Peluang pengembangan usaha ternak kelompok ini masih sangat terbuka. Hal ini dikarenakan sejak tahun 2016, pemerintah Kabupaten Blora memiliki program untuk menjadikan Blora sebagai sentra peternakan khusus sapi pedaging di wilayah Jawa Tengah.

Pada umumnya, penelitian terkait topik strategi pengembangan sudah banyak dilakukan, namun yang terkait usaha ternak sapi masih belum banyak. Meskipun sudah ada, unit analisis pada penelitian strategi pengembangan usaha ternak sapi banyak dilakukan pada tingkat perusahaan seperti pada PT Andini Persada Sejahtera (Nugroho, 2010), CV Mitra Tani Farm (Aisyah et al., 2013) dan PD. Kampung 99 Pepohonan (Rurkinantia et al., 2017). Penelitian strategi pengembangan ternak juga sudah dilakukan pada unit analisis berbasis wilayah yaitu desa (Siregar, 2015), kecamatan (Malotes, 2016), kabupaten (Suresti \& Wati, 2012), dan provinsi (Soetriono et al., 2019). Penelitian strategi pengembangan usaha ternak sapi pada kelompok ternak masih terbatas kecuali yang dilakukan oleh Suardi (2018) pada kelompok ternak yang tergabung pada Sekolah Peternakan Rakyat (SPR) di Kabupaten Muara Enim Provinsi Sumatra Selatan.

Meskipun sebagai kelompok ternak yang relatif baru berdiri, kelompok ternak Berkah Usaha sangat perlu untuk merumuskan strategi pengembangan usahanya agar lebih terencana.
Penelitian-penelitian terdahulu menunjukkan bahwa formulasi strategi pengembangan usaha ternak dapat dilakukan baik pada unit usaha atau perusahaan yang sudah lama berdiri seperti penelitian Aisyah et al. (2013) di CV Mitra Tani Farm yang berdiri tahun 2002, maupun pada usaha atau perusahaan yang baru berdiri seperti penelitian Nisa (2013) di PT. Catur Mitra Taruma yang baru berdiri pada tahun 2010 .

Selain itu, formulasi strategi pengembangan kelompok ternak Berkah Usaha ini sangat tepat waktunya karena berdasarkan prasurvei yang sudah dilakukan sebelumnya menunjukkan bahwa pada saat ini kelompok ternak Berkah Usaha ingin mengembangkan usaha ternak yang terencana dan terarah dengan baik kedepannya. Oleh karena itu perlu dikaji lingkungan usaha yang berkaitan dengan kelompok Berkah Usaha, baik secara eksternal maupun internal. Selanjutnya, juga perlu dikaji perumusan strategi pengembangan apa yang tepat untuk kelompok ternak Berkah Usaha untuk mendukung program Kabupaten Blora sebagai sentra produksi sapi pedaging di Jawa Tengah. Pada saat ini Kabupaten Blora menempati urutan pertama pada tingkat populasi sapi potong di Jawa Tengah yaitu mencapai 0,21 juta ekor sapi $(12,9$ persen dari total populasi sapi potong di Jawa Tengah) (BPS Jateng, 2018). Selain itu, pengembangan sapi pedaging rakyat termasuk prioritas penting untuk pencapaian target swasembada daging nasional, kontribusi ketahanan pangan dan peningkatan kesejahteraan peternak (Priyanto 2011; Rusdiana dan Praharani, 2018)

\section{TUJUAN PENELITIAN}

Berdasarkan latar belakang dan perumusan masalah yang telah diuraikan, tujuan penelitian ini adalah:

1. Mengidentifikasi apa saja faktor-faktor eksternal (peluang dan ancaman) dan internal (kekuatan dan kelemahan) yang memengaruhi kegiatan pengembangan usaha ternak kelompok Berkah Usaha.

2. Memformulasikan alternatif strategi pengembangan bisnis sesuai kondisi eksternal dan internal usaha ternak kelompok Berkah Usaha. 


\section{METODE}

\section{LOKASI DAN WAKTU PENELITIAN}

Penelitian ini dilaksanakan di kelompok ternak Berkah Usaha yang berlokasi di Desa Blungun Kecamatan Jepon Kabupaten Blora. Kelompok ternak yang berdiri tahun 2016 ini merupakan kelompok ternak yang berfokus pada usaha penggemukan sapi pedaging dan sedang merencanakan pengembangan usaha ternak kedepannya. Waktu pengumpulan data penelitian ini dilakukan selama bulan Februari 2019.

\section{JENIS DAN SUMBER DATA}

Jenis data yang digunakan dalam penelitian ini yaitu data primer dan sekunder. Data primer didapatkan dari wawancara, diskusi dan pengamatan langsung di lokasi penelitian. Pengumpulan data primer juga dilakukan dengan pengisian kuesioner. Adapun untuk data sekunder diperoleh dari sumber-sumber yang terkait dalam penelitian ini, seperti literatur, jurnal, skripsi dan artikel lain yang terkait dengan topik penelitian serta laporan internal dari kelompok ternak terkait, Badan Pusat Statistika (BPS) dan perpustakaan Institut Pertanian Bogor.

\section{METODE PENENTUAN RESPONDEN}

Penentuan responden dilakukan dengan sengaja berdasarkan kapabilitas dan pengalaman serta memiliki pengaruh kuat dalam menentukan kebijakan di kelompok ternak Berkah Usaha (key informant atau expert). Key informants dalam penelitian ini yaitu ketua kelompok, pengelola kandang (penggadu), kepala desa dan ketua Badan Usaha Milik Desa (BUMDES) desa Blungun.

\section{ANALISIS DATA}

Penelitian ini menggunakan dua tahap dalam merumuskan strategi pengembangan usaha kelompok Berkah Usaha, yaitu tahap masukan (input stage) dan tahap pencocokkan (matching stage) (David, 2011). Tahap keputusan (decision stage) tidak dilakukan dalam penelitian ini dikarenakan semua alternatif strategi yang diformulasikan pada tahap pencocokan diharapkan dapat direkomendasikan ke pihak manajemen kelompok ternak Berkah Usaha, sedangkan implementasi penerapan strategi disesuaikan dengan kondisi dan kebutuhan kelompok ternak tersebut. Sebelum melaksanakan tahap masukan dan pencocokan, dilakukan identifikasi visi misi kelompok ternak dan identifikasi faktor eksternal dan internal kelompok ternak Berkah Usaha.

Pada tahap pertama, input stage, peneliti melakukan review literatur dan wawancara secara mendalam dengan key informants untuk mengidentifikasi faktor eksternal dan internal. Selanjutnya, peneliti berdiskusi secara terpisah dengan masing-masing key informants untuk menganalisis faktor-faktor tersebut yang menjadi faktor kunci utama (key factors) baik eksternal maupun internal. Dari faktor kunci utama eksternal tersebut, peneliti mendiskusikan lagi dengan key informants untuk menentukan faktor kunci mana yang menjadi peluang dan ancaman. Hal yang sama juga dilakukan dalam menentukan faktor kunci mana yang menjadi kekuatan dan kelemahan dari faktor kunci internal.

Pada tahapan berikutnya, peneliti membuat daftar kedua faktor kunci eksternal dan faktor kunci internal tersebut dan meminta kepada key informants untuk memberikan pembobotan pada masing-masing faktor kunci tersebut (lihat Saaty, 1993). Selanjutnya, peneliti memasukkan faktor peluang dan ancaman ke dalam matriks external factor evaluation (EFE) dan faktor kekuatan dan kelemahan ke dalam matriks internal factor evaluation (IFE) untuk kemudian meminta key informants memberikan peringkat pada masing-masing faktor kunci tersebut (lihat David, 2011). Pada penelitian ini, prosedur penentuan bobot dan pemeringkatan baik faktor internal maupun eksternal masingmasing mengikuti Saaty (1993) dan David (2011).

Pada tahap kedua, matching stage, hasil skor pada pembobotan dan pemeringkatan matriks EFE dan IFE dimasukkan ke dalam matriks IE (Internal External) dan dilanjutkan menggunakan matriks SWOT sebagai alat untuk merumuskan alternatif strategi. Penggunaan kedua matriks tersebut dalam tahap pencocokan adalah bersifat saling melengkapi (komplementer), dimana strategi umum yang diperoleh dari matriks IE digunakan dalam merumuskan alternatif strategi pada matriks SWOT. Adapun tahapan formulasi strategi yang dapat diterapkan pada kelompok Berkah Usaha menggunakan 
matriks IE dan SWOT pada penelitian ini mengacu pada David (2011) dan Rangkuti (1998).

\section{HASIL DAN PEMBAHASAN}

Menentukan strategi yang tepat bagi sebuah usaha atau perusahaan membutuhkan identifikasi faktor kunci apa saja, baik eksternal maupun internal, yang dialami usaha atau perusahaan tersebut (David, 2011). Selanjutnya, dari faktor-faktor yang menjadi kunci tersebut dirumuskan strategi-strategi apa saja yang sesuai yang dapat menjadi alternatif strategi dalam pengembangan sebuah usaha atau perusahaan. Berikut ini disampaikan hasil identifikasi analisis lingkungan eksternal dan internal kelompok ternak Berkah Usaha.

\section{ANALISIS LINGKUNGAN EKSTERNAL}

Analisis faktor lingkungan eksternal yang diperoleh dari kelompok ternak Berkah Usaha menghasilkan faktor peluang dan ancaman bagi kelompok tersebut. Faktor-faktor tersebut diperoleh berdasarkan analisis lingkungan bisnis dari luar kelompok Berkah Usaha yang berada diluar kendali dari kelompok ternak ini. Identifikasi lingkungan eksternal bertujuan mengetahui segala peluang dan ancaman yang dapat memengaruhi keberlangsungan kegiatan maupun usaha ternak yang ada pada kelompok ternak Berkah Usaha. Analisis lingkungan eksternal terdiri dari lima aspek utama, yaitu analisis ekonomi, sosial, budaya, demografi dan lingkungan, hukum dan politik, teknologi dan persaingan (David, 2011).

Berdasarkan identifikasi dan observasi lapang yang telah dilakukan, terdapat dua belas faktor eksternal yang memengaruhi pengembangan bisnis kelompok ternak Berkah Usaha. Setelah dilakukan diskusi lanjutan dengan key informants, ada delapan faktor kunci eksternal yang terdiri dari empat faktor eksternal sebagai peluang dan empat faktor sebagai ancaman, yaitu:

\section{Peluang}

1. Permintaan daging sapi yang terus meningkat

2. Kebijakan pemerintah Blora sebagai sentra produksi sapi pedaging

3. Kerjasama antar kelompok ternak di wilayah Kecamatan Jepon
4. Perkembangan teknologi dan informasi yang semakin maju

\section{Ancaman}

1. Variabilitas cuaca

2. Pertumbuhan ekonomi yang fluktuatif

3. Kebijakan impor daging sapi dari pemerintah pusat

4. Infratruktur yang belum merata

\section{ANALISIS LINGKUNGAN INTERNAL}

Analisis lingkungan internal kelompok ternak Berkah Usaha bertujuan untuk memahami lingkungan organisasi secara internal yaitu kekuatan dan kelemahan. Pada penelitian ini, analisis internal kelompok ternak menggabungkan pendekatan fungsional perusahaan yang mencakup aspek-aspek manajemen, pemasaran, keuangan, produksi dan operasional, serta penelitian dan pengembangan (David, 2011) dan pendekatan pendekatan nilai-nilai koperasi/ kelompok social ekonomi seperti nilai kebersamaan, solidaritas, bertanggung jawab, dan keterbukaan.

Berdasarkan wawancara dan diskusi intensif dengan key informants, pada awal identifikasi lingkungan internal diperoleh tujuh belas faktor internal yang memengaruhi pengembangan usaha kelompok ternak Berkah Usaha. Namun berdasarkan diskusi lebih lanjut, ada sembilan faktor kunci internal yang terdiri dari lima faktor kunci sebagai kekuatan dan empat faktor sebagai kelemahan, yaitu:

\section{Kekuatan}

1. Bakalan sapi yang berkualitas

2. Ketersediaan sarana pendukung dan operasional

3. Pengolahan pakan konsentrat mandiri

4. Sistem keanggotaan dengan asas bersama

5. Sistem administrasi yang jelas dan transparan

\section{Kelemahan}

1. Lokasi usaha ternak yang kurang strategis

2. Jangkauan pemasaran yang belum luas

3. Limbah ternak yang belum dimanfaatkan jadi pupuk

4. Kapasitas kandang yang masih tergolong kecil 


\section{FORMULASI STRATEGI PENGEMBANGAN}

Tahap pertama formulasi strategi pengembangan bisnis kelompok ternak Berkah Usaha yaitu tahap masukan (input stage). Pada tahap masukan ini digunakan matriks EFE dan IFE. Berdasarkan identifikasi analisis lingkungan eksternal dan eksternal selanjutnya dilakukan analisis menggunakan matriks EFE dan IFE sehingga diperoleh hasil akhir dari pembobotan dan pemeringkatan faktor kunci eksternal (peluang dan ancaman) dan internal (kekuatan dan kelemahan) (Tabel 1 dan 2). Dari faktor kunci eksternal, peluang terpenting bagi kelompok Berkah Usaha yaitu melalui kebijakan pemerintah Blora yang sangat mendukung terhadap sapi pedaging dengan total skor sebesar 0,65 (Tabel 1). Bagi kelompok ternak terutama Berkah Usaha yang relatif baru berdiri, dukungan kebijakan dari pemerintah sangat penting. Hal ini mengindikasikan ada peluang-peluang program dari Pemerintah Daerah Kabupaten Blora yang sangat berkaitan dengan pengembangan ternak sapi rakyat. Adapun dari sisi ancaman, faktor yang harus diperhatikan kelompok ternak Berkah Usaha dalam pengembangan bisnis sapi pedaging yaitu variabilitas iklim dengan total skor 0,40 (Tabel 1). Hal ini diduga bahwa variabilitas iklim yang terjadi akhir-akhir ini dapat memengaruhi kesehatan hewan ternak sapi.

Secara keseluruhan, nilai total faktor kunci eksternal yang memengaruhi pengembangan usaha kelompok ternak Berkah Usaha yaitu 3,14 (Tabel 1). Nilai total tersebut lebih besar 3,0 mengindikasikan faktor eksternal pada posisi yang kuat yang berarti bahwa kelompok ternak Berkah Usaha harus terus memanfaatkan peluang yang ada untuk menghadapi ancaman yang mungkin muncul.

Di lain pihak, dari faktor kunci internal, kekuatan utama yang dimiliki kelompok ternak Berkah Usaha yaitu pada pengolahan pakan konsentrat mandiri dengan total skor 0,45 (Tabel 2). Pada saat ini, kelompok ternak Berkah Usaha sudah memiliki usaha pembuat pakan konsentrat sendiri untuk mengurangi ketergantungan dari luar. Kedepannya, usaha pengolahan pakan konsentrat ini juga untuk memenuhi kebutuhan pakan konsentrat petenak dan kelompok ternak lainnya. Adapun kelemahan utama yang dimiliki kelompok ternak Berkah Usaha yaitu limbah ternak yang belum dimanfaatkan dengan baik yaitu memiliki total skor 0,33 (Tabel 2). Pemanfaatan limbah ternak yang belum optimal ini diduga terkait dengan kapasitas sumberdaya manusia kelompok ternak dan ketersediaan teknologi.

Secara keseluruhan, nilai total faktor kunci internal yang memengaruhi pengembangan usaha kelompok ternak Berkah Usaha yaitu 2,71 (Tabel 2). Nilai IFE tersebut lebih besar dari 2,5 dan kurang dari 3,0 mengindikasikan bahwa faktor kunci internal kelompok ternak Berkah Usaha berada pada posisi sedang. Hal ini mengindikasikan bahwa kelompok ternak Berkah Usaha harus terus meningkatkan kekuatan yang dimiliki untuk menutupi kelemahan yang ada.

Tabel 1. Hasil Matriks EFE

\begin{tabular}{|c|c|c|c|c|}
\hline No & Faktor Kunci Eksternal & $\begin{array}{c}\text { Bobot } \\
(a)\end{array}$ & $\begin{array}{c}\text { Peringkat } \\
\text { (b) }\end{array}$ & $\begin{array}{c}\text { Total Skor } \\
(a x b)\end{array}$ \\
\hline \multicolumn{5}{|c|}{ Peluang } \\
\hline \multirow{2}{*}{$\begin{array}{l}1 \\
2\end{array}$} & Kebijakan Pemerintah Blora pada program sapi pedaging & 0,16 & 4,0 & 0,65 \\
\hline & $\begin{array}{l}\text { Perkembangan teknologi dan informasi yang semakin } \\
\text { maju }\end{array}$ & 0,13 & 3,5 & 0,46 \\
\hline 3 & Kenaikan permintaan daging sapi tiap tahunnya & 0,12 & 3,5 & 0,40 \\
\hline 4 & $\begin{array}{l}\text { Kerjasama antar kelompok ternak di Kecamatan Jepon } \\
\text { Total Peluang }\end{array}$ & 0,09 & 3,5 & $\begin{array}{l}0,32 \\
\mathbf{1 , 8 4}\end{array}$ \\
\hline \multicolumn{5}{|c|}{ Ancaman } \\
\hline 1 & Variabilitas cuaca & 0,13 & 3,0 & 0,40 \\
\hline 2 & Perubahan ekonomi yang fluktuatif & 0,12 & 3,0 & 0,35 \\
\hline 3 & Kebijakan impor daging sapi dari pemerintah pusat & 0,14 & 2,0 & 0,28 \\
\hline \multirow[t]{2}{*}{4} & $\begin{array}{l}\text { Infrastruktur yang belum merata } \\
\text { Total Ancaman }\end{array}$ & 0,11 & 2,5 & $\begin{array}{l}0,28 \\
\mathbf{1 , 3 0}\end{array}$ \\
\hline & Total & & & 3,14 \\
\hline
\end{tabular}


Tabel 2. Hasil Matriks IFE

\begin{tabular}{|c|c|c|c|c|}
\hline No & Faktor Kunci Internal & $\begin{array}{c}\text { Bobot } \\
\text { (a) }\end{array}$ & $\begin{array}{l}\text { Peringkat } \\
\text { (b) }\end{array}$ & $\begin{array}{c}\text { Total Skor } \\
\text { (axb) }\end{array}$ \\
\hline \multicolumn{5}{|c|}{ Kekuatan } \\
\hline 1 & Pengolahan pakan konsentrat mandiri & 0,11 & 4,0 & 0,45 \\
\hline 2 & Bakalan sapi yang berkualitas & 0,10 & 4,0 & 0,38 \\
\hline 3 & Ketersediaan sarana pendukung dan operasional & 0,11 & 3,5 & 0,37 \\
\hline 4 & Sistem administrasi yang jelas dan transparan & 0,10 & 3,5 & 0,35 \\
\hline \multirow[t]{2}{*}{5} & Sistem keanggotaan dengan asas bersama & 0,07 & 4,0 & 0,27 \\
\hline & Total Kekuatan & & & 1,83 \\
\hline \multicolumn{5}{|c|}{ Kelemahan } \\
\hline 1 & Limbah ternak belum dimanfaatkan jadi pupuk & 0,16 & 2,0 & 0,33 \\
\hline 2 & Kapasitas kandang masih tergolong kecil & 0,13 & 2,0 & 0,26 \\
\hline 3 & Lokasi usaha ternak kurang strategis & 0,15 & 1,5 & 0,22 \\
\hline \multirow[t]{3}{*}{4} & Jangkauan pemasaran belum luas & 0,07 & 1,0 & 0,07 \\
\hline & Total Kelemahan & & & 0,89 \\
\hline & Total & & & 2,71 \\
\hline
\end{tabular}

Selanjutnya, tahap formulasi pengembangan bisnis kelompok ternak Berkah Usaha yaitu tahap pencocokan (matching stage). Seperti dijelaskan dalam metode penelitian, penelitian ini menggunakan gabungan matriks IE dan SWOT dalam merumuskan strategi pada tahap pencocokan. Pertama, berdasarkan hasil total skor matriks EFE $(3,14)$ dan IFE $(2,71)$ dimasukan ke dalam matriks IE (Gambar 2). Berdasarkan Gambar 2, dapat dilihat bahwa posisi kelompok ternak Berkah Usaha berada pada sel II, yaitu pada strategi umum yaitu tumbuh dan berkembang (growth and build) (David, 2011). Berdasarkan posisi pada matriks IE tersebut, alternatif strategi yang dapt dikembangkan oleh kelompok ternak Berkah Usaha yaitu strategi integrasi dan intensif (David, 2011).

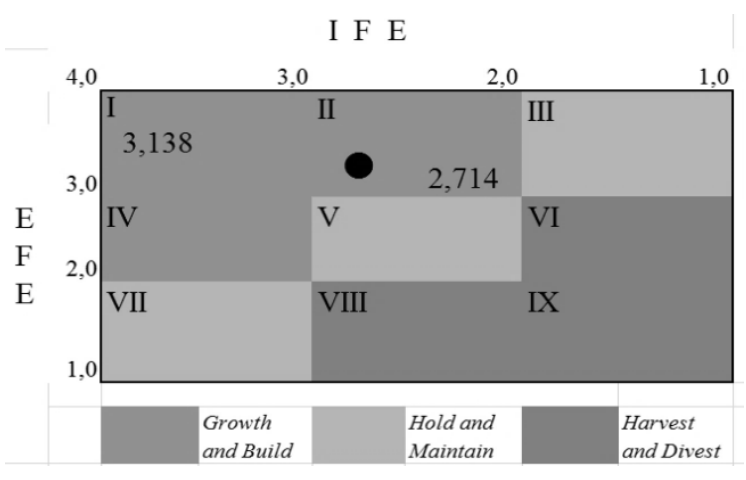

Gambar 2. Hasil Matriks IE
Kedua, faktor kunci eksternal (peluang dan ancaman) dan faktor kunci internal (kekuatan dan kelemahan) dimasukkan dalam matriks SWOT (Tabel 3). Matriks SOWT digunakan untuk merumuskan formulasi strategi pengembangan bisnis kelompok ternak Berkah Usaha lebih detail. Meskipun demikian, formulasi alternative strategi pengembangan bisnis pada matriks SWOT ini tetap mengacu pada strategi umum yang dihasilkan dari matriks IE yaitu tumbuh dan berkembang dengan alternatif strategi berupa strategi integrase dan intensif. Sesuai ketentuan, dari matriks SWOT diperoleh klasifikasi strategi menjadi empat strategi yaitu strategi SO (kekuatanpeluang), strategi WO (kelemahan-peluang), strategi ST (kekuatan-ancaman), dan strategi WT (kelemahan-ancaman). Berdasarkan analisis matriks IE dan SWOT tersebut, diperoleh enam alternatif strategi pengembangan bisnis kelompok ternak Berkah Usaha, yaitu (Tabel 3):

1. Pengadaan bakalan sapi berkualitas dengan menjalin kerjasama tetap dengan Pemda Blora (strategi SO)

2. Melakukan standardisasi kualitas pakan konsentrat (strategi SO)

3. Pemanfaatan limbah kotoran ternak untuk pupuk kandang sebagai usaha alternatif (strategi WO)

4. Bekerjasama dengan kelompok-kelompok ternak lain di Kecamatan Jepon untuk membangun kawasan peternakan atau Sekolah Peternakan Rakyat (SPR) (strategi WO) 
Tabel 3. Hasil Matriks SWOT

\begin{tabular}{|c|c|c|}
\hline & Strengths & Weaknesses \\
\hline & $\begin{array}{l}\text { 1. Pengolahan pakan } \\
\text { konsentrat secara mandiri } \\
\text { 2. Bakalan sapi yang } \\
\text { berkualitas } \\
\text { 3. Ketersediaan sarana } \\
\text { pendukung dan operasional } \\
\text { 4. Sistem administrasi yang } \\
\text { jelas dan transparan } \\
\text { 5. Sistem keanggotaan dengan } \\
\text { asas Bersama }\end{array}$ & $\begin{array}{l}\text { 1. Limbah ternak belum } \\
\text { dimanfaatkan jadi pupuk } \\
\text { 2. Kapasitas kandang masih } \\
\text { kecil } \\
\text { 3. Lokasi usaha ternak } \\
\text { kurang strategis } \\
\text { 4. Jangkauan pemasaran } \\
\text { belum luas }\end{array}$ \\
\hline Opportunities & Strategi SO & Strategi WO \\
\hline $\begin{array}{l}\text { 1. Kebijakan pemerintah Blora } \\
\text { yang sangat mendukung } \\
\text { terhadap sapi pedaging } \\
\text { 2. Perkembangan Teknologi } \\
\text { dan Informasi } \\
\text { 3. Kenaikan permintaan tiap } \\
\text { tahunnya } \\
\text { 4. Kerjasama antar kelompok } \\
\text { ternak di wilayah } \\
\text { kecamatan Jepon }\end{array}$ & $\begin{array}{l}\text { Pengadaan bakalan sapi } \\
\text { berkutalitas dengan menjalin } \\
\text { kerjasama tetap dengan Pemda } \\
\text { Blora (S2, S3, 01, 03, 04) } \\
\text { Standardisasi dan peningkatan } \\
\text { kualitas pakan konsentrat (S1, } \\
\text { S3, S5, O2) }\end{array}$ & $\begin{array}{l}\text { Pemanfaatan limbah kotoran } \\
\text { ternak untuk pupuk kandang } \\
\text { sebagai usaha alternatif (W1, } \\
\text { O2) } \\
\text { Bekerjasama membangun } \\
\text { kawasan peternakan atau SPR } \\
\text { di kecamatan Jepon (W2, W3, } \\
01,04)\end{array}$ \\
\hline Threats & Strategi ST & Strategi WT \\
\hline $\begin{array}{l}\text { 1. Variabilitas iklim } \\
\text { 2. Perubahan ekonomi yang } \\
\text { fluktuatif } \\
\text { 3. Kebijakan impor daging sapi } \\
\text { dari pemerintah pusat } \\
\text { 4. Infrastruktur yang belum } \\
\text { merata }\end{array}$ & $\begin{array}{l}\text { Menjalin kemitraan dengan } \\
\text { perusahaan induk ternak sapi } \\
(\mathrm{S} 2, \mathrm{~S} 3, \mathrm{~S} 5, \mathrm{~T} 2, \mathrm{~T} 3)\end{array}$ & $\begin{array}{l}\text { Perluasan kandang ternak } \\
\text { dengan sistem bangunan yang } \\
\text { tertutup (W2, W3, T1) }\end{array}$ \\
\hline
\end{tabular}

5. Menjalin kemitraan tetap dengan perusahaan ternak sapi PT. Wahyu Utama (strategi ST); dan

6. Perluasan kandang ternak dengan sistem tertutup (strategi WT)

Berdasarkan keenam alternatif strategi tersebut, kelompok ternak Berkah Usaha dapat mengimplementasikan semua alternatif strategi disesuaikan dengan visi misi, kondisi internal, kebutuhan dan rencana pengembangan bisnis kelompok ternak Berkah Usaha kedepannya. Pada tahap implementasi, pengelola kelompok ternak Berkah Usaha dapat mengadakan rapat anggota untuk mendiskusikan keenam alternatif strategi tersebut untuk dibuatkan prioritas strategi. Meskipun demikian, ada dua strategi yang dapat dipertimbangkan menjadi strategi prioritas kelompok ternak Berkah Usaha yaitu strategi kerjasama dengan kelompok ternak lain dalam membangun kawasan peternakan sapi pedaging atau sekolah peternakan rakyat (SPR) di Kecamatan Jepon dan pengadaan bakalan sapi berkualitas.

Pertama, strategi menjalin kerjasama dengan kelompok-kelompok ternak lain di Kecamatan Jepon untuk membangun kawasan peternakan atau sekolah peternakan rakyat (SPR). Strategi bekerjasama dengan kelompokkelompok ternak lain sangat penting dan sangat sesuai dengan kebijakan atau program pemerintah yaitu, pembentukan kawasan peternakan yaitu desa-desa dalam satu kecamatan, dalam hal ini kelompok-kelompok ternak dalam setiap desa, bekerjasama dalam membangun usaha peternakan sapi yang harmonis dan sinergis. Sebagai contoh, kerjasama tersebut dapat diwujudkan dalam pengadaan sarana produksi ternak dan pemasaran bersama serta dalam upaya mencapai economic of scale. Pembentukan kawasan peternakan atau SPR ini juga dapat 
melibatkan kerjasama dengan multipihak lain seperti perusahaan yang sudah berpengalaman dalam usaha penggemukan sapi, dalam hal ini PT Wahyu Utama, Dinas-Dinas terkait dan perguruan tinggi.

Kedua, kelompok ternak Berkah Usaha perlu menjamin ketersediaan pengadaan bakalan sapi berkualitas diantaranya kerjasama dengan Pemda Blora. Hal ini berdasarkan adanya peluang eksternal dan kekuatan internal yang dimiliki oleh kelompok ternak Berkah Usaha. Peluang eksternal disini yaitu keberadaan bakalan sapi berkualitas yang dimiliki Pemda Blora sebagai bagian dari program Pemda untuk mewujudkan Kabupaten Blora sebagai salah satu sentra produksi sapi di Jawa Tengah. Strategi ini dapat dipertimbangkan menjadi prioritas jangka pendek karena ketersediaan dan keterjaminan bakalan sapi yang berkualitas sangat penting dalam keberhasilan usaha penggemukan sapi pedaging.

Berdasarkan hal tersebut, dalam jangka pendek, Kelompok Ternak Berkah Usaha dapat mengaplikasikan prioritas strategi utama tersebut. Hal ini dikarenakan sebagai kelompok ternak yang relatif baru dan seperti pada umumnya kelompok ternak lainnya yang menghadapi beberapa keterbatasan, memilih prioritas strategi sangat penting karena terkait dengan pengalokasian sumberdaya. Meskipun demikian, kedepannya kelompok Berkah Usaha juga dapat menerapkan alternatif-alternatif strategi lainnya dalam upaya pengembangan usaha ternak sapi.

\section{SIMPULAN DAN SARAN}

\section{SIMPULAN}

1. Berdasarkan hasil analisis lingkungan eksternal dan internal dari kelompok ternak Berkah Usaha didapatkan delapan faktor kunci eksternal dan sembilan faktor kunci internal. Faktor kunci utama internal kelompok yaitu usaha pakan ternak dan bakalan sapi yang berkualitas sedangkan faktor kunci utama eksternal yaitu kebijakan pemerintah dan variabilitas iklim.

2. Berdasarkan matriks IE, kelompok Berkah Usaha pada kondisi tumbuh dan membangun (growth and build), dan berdasarkan matriks SWOT, ada enam alternatif strategi pengembangan usaha kelompok ternak Berkah Usaha diantaranya yaitu kerjasama dengan kelompok ternak lain dalam membangun kawasan peternakan sapi pedaging atau sekolah peternakan rakyat (SPR) di Kecamatan Jepon dan pengadaan bakalan sapi berkualitas.

\section{SARAN}

Hasil formulasi strategi dapat dijalankan untuk pengembangan kelompok Berkah Usaha yaitu menjalin kerjasama multipihak baik dengan Pemerintah Daerah Blora, swasta (PT Wahyu Utama), kelompok ternak lain di Kecamatan Jepon dan perguruan tinggi. Langkah yang dapat dilakukan yaitu:

1. Menginisiasi membangun komunikasi dengan kelompok-kelompok ternak dan penyuluh di kecamatan Jepon untuk membangun kawasan peternakan atau sekolah peternakan rakyat (SPR) yang bertujuan untuk bekerjasama menignkatkan skala ekonomi usaha ternak, menjalin relasi dan meningkatkan bargaining power bagi seluruh kelompok ternak yang tergabung di wilayah Kecamatan Jepon.

2. Membuat kesepakatan bersama antara pemerintah Blora, perusahaan ternak sapi PT. Wahyu Utama untuk menjadi mitra tetap bagi kelompok Berkah Usaha dalam hal pengadaan bakalan sapi dan distribusi sapi.

3. Melakukan kerjasama dengan ahli peternakan, dinas peternakan, dan lembaga terkait dalam meningkatkan kapasitas baik kapasitas sumberdaya manusia, kewirausahaan, pengelolaan usaha dan bisnis dan kepemimpinan.

\section{DAFTAR PUSTAKA}

Aisyah SA, Sanim, B dan Maulana A. 2013. Strategi Pengembangan Usaha Sapi Potong (Studi Kasus CV Mitra Tani Farm). Jurnal Manajemen \& Agribisnis, 10(2), pp.109-116.

[BPS] Badan Pusat Statistika. 2018a. Jumlah Hewan Ternak yang Dipotong dan Dilaporkan 2014-2017. 
BPS] Badan Pusat Statistika. 2018b. Populasi Sapi Pedaging Menurut Provinsi di Indonesia 2014-2017.

[BPS Jateng] Badan Pusat Statistika Provinsi Jawa Tengah. 2018. Populasi Ternak menurut Kabupaten/Kota dan Jenis Ternak. [Diakses pada 30 Mei 2019]. Tersedia pada: https://jateng.bps.go.id/statictable/2016/0 8/23/1317/populasi-ternak-menurutkabupaten-kota-dan-jenis-ternak-diprovinsi-jawa-tengah-2015.html.

David FR. 2011. Manajemen Strategis. Dono Sunardi, penerjemah; Palupi Wuniarti, editor. Jakarta (ID): Penerbit Salemba Empat. Terjemahan dari: Strategic Management. Edisi ke-15.

DITJEN PKH. 2017. Statistik Peternakan dan Kesehatan Hewan 2017. Jakarta (ID). Penerbit Direktorat Jendral Peternakan dan Kesehatan Hewan Kementrian Pertanian Republik Indonesia.

Ismono $\mathrm{H}$, Erwanto, Lestari DA, Sayekti WD, Haryono D, Adhianto K, Nasution H, Riyadi HE. 2015. Subsektor Agribisnis Usaha Rumah Tangga Budidaya Sapi dan Target Swasembada (Analisis Tematik ST2013). Jakarta (ID). Penerbit [BPS] Badan Pusat Statistik.

[Kementan] Kementrian Pertanian. 2018. Impor Daging Sapi di Indonesia Tahun 2014-2017 [Diakses pada Desember 2018]. Tersedia pada:

https://databoks.katadata.co.id/datapublish /2017/03/24/2010-2016-impor-dagingsapi-indonesia-fluktuatif.

Malotes J. 2016. Strategi Pengembangan Usaha Peternakan Sapi Potong di Kecamatan Tinangkung Utara Kabupaten Banggai Kepulauan. Agroland: Jurnal Ilmu-ilmu Pertanian, 23(3), pp.198-207.

Nisa C. 2013. Analisis Kelayakan Bisnis Penggemukan Sapi Potong pada PT Catur Mitra Taruma di Desa Cariu Kecamatan Cariu Kabupaten Bogor [skripsi]. Bogor (ID): Institut Pertanian Bogor.

Nugroho S. 2010. Strategi Pengembangan Usaha Peternakan Sapi Potong di PT Andini Persada
Sejahtera [tesis]. Bogor: Institut Pertanian Bogor.

Priyanto D. 2011. Strategi Pengembangan Usaha Ternak Sapi Potong dalam Mendukung Program Swasembada Daging Sapi dan Kerbau tahun 2014. Jurnal Litbang Pertanian, 30(3), p.108-116.

Rangkuti F. 1998. Analisis SWOT Teknik Membedah Kasus Bisnis. Gramedia Pustaka Utama.

Reardon T, Stringer R, Timmer CP, Minot N dan Daryanto A. 2015. Transformation of the Indonesian Agrifood System and the Future beyond Rice: A Special Issue. Bulletin of Indonesian Economic Studies, 51(3), p.369373.

Rurkinantia A, Oktaviani R. dan Sanim B. 2017. Strategi Pengembangan Bisnis Pemotongan Sapi. Jurnal Aplikasi Bisnis dan Manajemen (JABM), 3(3), p.253.

Rusdiana S dan Praharani L. 2018. Pengembangan Peternakan Rakyat Sapi Potong: Kebijakan Swasembada Daging Sapi dan Kelayakan Usaha Ternak. Forum penelitian Agro Ekonomi, 36(2), p. 97-116.

Saaty TL. 1993. Pengambilan Keputusan. Jakarta (ID): PT Pustaka Binaman Pressindo.

Siregar G. 2015. Analisis Kelayakan dan Strategi Pengembangan Usaha Ternak Sapi Potong. AGRIUM: Jurnal Ilmu Pertanian, 17(3).

Soetriono S, Soejono D, Zahrosa, DB, Maharani AD, dan Amam A. 2019. Strategi Pengembangan dan Diversifikasi Sapi Potong di Jawa Timur. Jurnal Ilmu dan Teknologi Peternakan Tropis, 6(2), p.138-145

Suardi AN. 2018. Strategi dan Model Pengembangan Bisnis Kelompok Ternak Sapi Potong pada Sekolah Peternakan Rakyat di Kabupaten Muara Enim [skripsi]. Bogor (ID): Institut Pertanian Bogor.

Suresti A dan Wati R. 2012. Strategi Pengembangan Usaha Peternakan Sapi Potong di Kabupaten Pesisir Selatan. Jurnal Peternakan Indonesia (Indonesian Journal of Animal Science), 14(1), p.249-262 